\title{
MAKNA SLOGAN "WE'LL TAKE CARE OF YOU WHEREVER YOU ARE" PADA IKLAN SAMSUNG INDIA
}

\author{
Lina $^{1 *}$, Ressy Damayanti $^{2}$ \\ ${ }^{1,2}$ Institut Komunikasi dan Bisnis LSPR, Jakarta, Indonesia \\ *linaerizal@gmail.com
}

Submitted: 08-07-2021, Revision: 12-07-2021, Accepted: 25-12-2021

\begin{abstract}
The development of the world of advertising today causes many new products and services to appear. This study aims to determine the meaning of the message conveyed in the advertisement based on the signs contained in it. This study uses a qualitative methodology with semiotic theory by Roland Barthes, based on the signifier and denotation, connotation, and myth aspects so that the advertisement can be dissected in detail and find meaning in the advertisement. The meaning of the Samsung India advertisement shows that the services offered by Samsung India are unusual because Samsung is able to deliver services directly to the customer's location even though they have to travel long distances with several obstacles. Another new finding can be seen that the company, namely Samsung India, is a credible company because it continues to highlight the Samsung logo in the advertisement. Based on the results of the study, the researcher provides academic and practical advice. Academic advice is to get more in-depth teaching about Roland Barthes' semiotics so that in future research, this research can be a reference. Practical advice, Samsung India should continue to develop creative, informative and communicative ideas or themes from campaigns for future advertisements.
\end{abstract}

Keywords: Semiotics, ads, sign, Samsung India.

\begin{abstract}
Abstrak
Berkembangnya dunia periklanan saat ini menyebabkan banyak produk baru serta layanan jasa bermunculan. Penelitian ini bertujuan untuk mengetahui makna pesan yang disampaikan di dalam iklan berdasarkan tanda-tanda yang terdapat di dalamnya. Penelitian ini menggunakan metodologi kualitatif dengan teori semiotika oleh Roland Barthes, berdasarkan aspek penanda dan aspek denotasi, kontotasi, dan mitos agar iklan mampu dibedah secara rinci serta menemukan makna di dalam iklan tersebut. Makna iklan Samsung India menunjukkan bahwa layanan yang ditawarkan Samsung India tidaklah biasa karena Samsung mampu mengantarkan pelayanan langsung ke lokasi pelanggan tersebut meskipun harus menempuh jarak yang jauh dengan beberapa rintangan. Temuan baru lainnya dapat dilihat bahwa pihak perusahaan, yaitu Samsung India merupakan perusahaan yang kredibel karena terus menonjolkan logo Samsung didalam iklan tersebut. Berdasarkan hasil penelitian, peneliti memberikan saran secara akademis dan praktis. Saran akademis, agar mendapatkan pengajaran lebih mendalam mengenai semiotika Roland Barthes sehingga pada penelitian selanjutnya, penelitian ini mampu menjadi acuan. Saran praktis, sebaiknya iklan kampanye yang dilakukan Samsung India harus terus mengembangkan ide-ide atau tema dari kampanye yang kreatif, informatif, dan komunikatif untuk iklan mendatang.
\end{abstract}

Kata Kunci: Semiotika, iklan, tanda, Samsung India.

\section{PENDAHULUAN}

Perkembangan teknologi membawa perubahan terhadap perilaku manusia dalam melakukan interaksi dan transaksi mulai dari pencarian informasi, penyampaian fedback dan juga referensi.(Rahayu \& Poerana, 2020). Media online lahir di era teknologi informasi yang berkembang sangat pesat, dengan dukungan internet sebagai basis penyebaran informasi, media online hadir 
sebagai pilihan baru untuk memenuhi kebutuhan informasi (Rosidin \& Hamid, 2020).

Iklan digunakan untuk menginformasikan serta meyakinkan orang untuk membeli produk dan layanan yang dijual oleh pengiklan (Oputa \& Ahmad, 2019). Beberapa iklan dirancang untuk mengubah perspektif konsumen pada perusahaan yang diiklankan, sementara beberapa dibuat untuk membujuk konsumen untuk membeli produk mereka (Fernando, 2019). Akhir-akhir ini perkembangan iklan begitu pesat dan marak bermunculan, baik itu dalam media cetak, elektronik, media online, maupun media luar ruang. Hal itu terjadi karena semua perusahaan bersaing agar mempengaruhi pikiran konsumen tentang produk yang diiklankan (Anggakara \& Gunawan, 2017).

Dewasa ini, perkembangan iklan menggunakan media online sangat marak terjadi. Salah satu yang menjadi sasaran bagi periklan adalah Youtube (Najam, 2019). Youtube merupakan salah satu media sosial yang dapat digunakan untuk memasarkan produk (Sukamto \& Wijaksana, 2017). Youtube menjadi media yang banyak diminati perusahaan (Tito \& Gabriella, 2019) karena penggunanya yang meluas ke seluruh kalangan masyarakat sehingga peluang untuk menarik minat beli masyarakat akan meningkat. Hal ini terjadi karena pengguna ini terjadi karena pengguna Youtube dapat sewaktu-waktu dapat membuat pengguna mengklik tautan yang muncul secara sengaja atau tidak (Christian, 2019).

Salah satu perusahaan yang memanfaatkan iklan adalah Samsung. Saat ini, Samsung memiliki perkembangan yang sangat signifikan dari tahun ke tahun, beserta dengan inovasi menarik yang tak terhitung jumlahnya (Gunawan, 2018). Iklan Samsung termasuk dalam iklan media internet karena iklan tersebut dirilis di situs YouTube (Rahayu \& Dewi, 2018). Perilisan iklan di Youtube bertujuan agar produk-produk
Samsung semakin dikenal seluruh masyarakat dan menarik minat pelanggan.

Beberapa iklan Samsung mencapai puluhan hingga ratusan juta penonton. Terutama pada iklan Samsung yang berjudul "Samsung India Service - We'll Take Care of You, Wherever You Are". Hal ini menarik untuk diteliti karena jumlah penonton ratusan juta serta banyak pengguna yang menyukai iklan tersebut. Iklan ini diunggah di Youtube oleh Samsung India pada tanggal 30 Desember 2016 yang berdurasi 4 menit dan sudah di tonton sejumlah 210,974,183 penonton dengan 184,774 likes (Youtube, 2016). Pembuatan iklan memerlukan berbagai dukungan visualisasi, seperti alat, teknologi, dan sumber daya manusia. Teknik pengambilan gambar (shot) sering mempengaruhi jalannya cerita (Tobing, 2018: 7) dan sudut pengambilan gambar (angle) dalam jarak tertentu mempengaruhi hasil yang dicapai (Bonafix, 2011). Selain itu, pencahayaan (lighting), backsound, make up, dan wardrobe akan mendukung keberhasilan dalam penyampaian makna suatu iklan (Prasetya, 2019: 39). Melalui aspek-aspek tersebut, Samsung India Service pun berhasil menjadi nomer 1 sebagai Youtube's Top 10 Ads of 2017 (Gesenhues, 2017).

Hal yang menarik dalam iklan ialah hal yang berkaitan dengan simbol-simbol atau tanda yang ada dalam iklan komersial tersebut. Pesan yang disampaikan melalui iklan ini juga merupakan komunikasi nonverbal yang memiliki sejumlah tanda. Maka dari itu, untuk dapat memahami sebuah makna yang ingin disampaikan oleh iklan Samsung India Service "We'll take care of you, wherever you are" diperlukan penelitian semiotika hal inilah yang membuat peneliti tertarik dalam memilih topik ini. Penelitian semiotika digunakan dalam berbagai macam penelitian terkait visualisasi. Dalam penelitian yang menggunakan analisis semiotika berfokus pada tanda, simbol, dan makna yang ada dalam iklan (Wahjuwibowo, 2018: 7). selain 
itu, perilaku nonverbal mempengaruhi penyampaian makna suatu pesan (Morissan, 2013: 140).

Roland Barthes berpendapat bahwa semiologi pada dasarnya untuk mempelajari bagaimana kemanusiaan (humanity) memaknai hal-hal (things) (Sobur, 2009: 15). Konsep pemikiran Barthes kepada semiotik terkenal dengan konsep mythologies atau mitos yang mencakup beberapa hal, yaitu denotasi, konotasi, dan mitos (Prasetya, 2019: 14). Barthes mengawali konsep pemaknaan tanda dalam analisis semiotika dengan mengangkat pikiran Saussure serta menambahkan konsep denotasi dan konotasi. Denotasi merupakan wujud fisik, apa yang ditampakkan, dan bagaimana bentuknya. Sedangkan konotatif ialah sebuah tanda dengan maksud tertentu dan dapat dikomunikasikan (Prasetya, 2019: 12)

Penelitian sebelumnya yang berjudul "Representasi Maskulinitas Dalam Iklan Televisi Pond's Men \#Lelakimasakini (Analisis Semiotika Roland Barthes Terhadap Representasi Maskulinitas)", oleh Yuliyanti et al. (2017) dalam Jurnal Komunikasi. Penelitiannya menunjukkan hasil makna denotasi, konotasi, dan mitos terdapat di dalam iklan tersebut. Iklan tersebut mampu merepresentasikan maskulinitas dengan edisi \#LelakiMasaKini. Hal yang berbeda dengan penelitian ini adalah pengambilan sumber media iklan yang berasal dari Youtube, oleh karena itu, saat ini Youtube menjadi pertimbangan penting bagi produsen untuk mengiklankan produknya di Youtube daripada di televisi.

Penelitian lainnya adalah milik Kusumasari (2014) dalam Jurnal J-IKA yang berjudul "Makna Iklan Oreo Versi "Pilih Handphone Atau Oreo" (Studi Fenomenologi Iklan Oreo Versi "Pilih Handphone atau Oreo" Menurut Mahasiswa BSI Bandung)" yang menggunakan metode Fenomenologi Schutz melalui teori interaksi simbolik. Hasilnya, makna iklan tersebut adalah perkembangan teknologi yang mengubah perilaku orang tua, dan penjagaan hubungan baik antar anak dengan orangtuanya sehingga anak diminta untuk memilih antara handphone atau Oreo. Hal yang berbeda dari penelitian ini adalah penggunaan teori semiotika oleh Roland Barthes untuk menganalisis iklan yang tidak hanya memaknai tentang interaksi simbolik, namun juga makna lain megenai dekonotasi, konotasi, serta mitos yang tergantung dalam sebuah iklan.

Selanjutnya, penelitian milik Arasid \& Hapsari (2019) dalam jurnal J-IKA dengan judul "Pemaknaan Ilustrasi Berita Infografis Pada Media Online: Analisis semiotika pada Instagram CNBC Indonesia”. Analisis semiotika Roland Barthes digunakan dalam penelitian ini menunjukkan hasil bahwa dalam setiap ilustrasi pada berita infografis CNBC Indonesia melalui Instagram akan selalu memiliki makna denotasi di dalamnya. Dari penelitian tersebut dapat disimpulkan untuk memahami sebuah ilustrasi kita dianjurkan untuk lebih melihat aspek denotasi dan konotasi dengan mitos sebagai pendamping. Berbeda dengan penelitian ini yang memanfaatkan analisis semiotika Barthes untuk menganalisis makna denotatif, konotatif, dan mitos dalam iklan Samsung India Service "We'll take care of you, wherever you are".

Oleh karena itu, penelitian ini dilakukan untuk menganalisis makna denotatif, konotatif, dan mitos yang terdapat dalam iklan Samsung India Service "We'll take care of you, wherever you are" agar menjadi bahan evaluasi dan motivasi perusahaan lain dalam menampilkan iklan di Youtube. Iklan ini menarik untuk diteliti karena kebanyakan dari penonton iklan tersebut memberikan respon positif terhadap iklan tersebut, tidak hanya para penonton, beberapa website dan banyak pula youtuber yang membuat video reaction saat menonton iklan video tersebut. Maka dari itu, untuk dapat memahami sebuah makna yang ingin disampaikan oleh iklan Samsung India Service Service "We'll take care of you, wherever you are" 
diperlukan penelitian semiotika. Analisis yang dilakukan peneliti ialah analisis semiotika Roland Barthes merupakan analisis interpretif sehingga hasil penafsiran terhadap tanda yang ada didalam iklan tersebut hanya bergantung kepada wawasan peneliti yang bersifat subjektif dari sisi pemahaman peneliti.

\section{METODOLOGI}

Metode yang digunakan oleh peneliti merupakan metode kualitatif, hal ini ditunjang dari objek penelitian yang dipilih. Metode pengumpulan data diperoleh dari pengamatan secara menyeluruh terhadap objek penelitian, dengan menyaksikan iklan Samsung India Service "We'll take care of you, wherever you are". Data yang dibutuhkan oleh peneliti berupa Data primer dan Data sekunder. Data primer diperoleh dari penelitian ini yaitu dengan melakukan observasi dan analisa pada iklan Samsung India Service "We'll take care of you, wherever you are" yang dipublikasikan melalui akun YouTube Samsung India. Sedangkan, data sekunder dapat diperoleh dari jurnal-jurnal ilmiah, penelitian terdahulu, situs, media online serta offline dari sumber yang kredibel.

Unit analisis data yaitu iklan yang akan jadi objek penelitian adalah "Samsung India Service "We'll take care of you, wherever you are" yang berdurasi 4 menit yang dipublikasikan pada tanggal 30 Desember 2016 di Youtube. Data yang digunakan oleh peneliti merupakan data berbentuk video dengan format MP4 yang telah diunduh dari YouTube Samsung India dengan menggunakan aplikasi YouTube Downloader.

Teknik analisis data yang digunakan pada penelitian ini adalah analisis semiotika di tinjau oleh Roland Barthes yang tertuju kepada hubungan antara tanda dengan pengirim dan penerima. Langkah-langkah analisa yang dilakukan adalah (1) Menyaksikan iklan Samsung India Service "We'll take care of you, wherever you are";
(2) Memahami tanda-tanda signifikan yang telah ditentukan sesuai dengan analisis Roland Barthes; (3) Tanda-tanda atau simbol yang ada akan diinterpretasi oleh peneliti berdasarkan makna denotasi, konotasi dan mitos berdasarkan teori semiotika Roland Barthes; (4) Mengelompokkan simbol atau tanda yang muncul di dalam iklan berdasarkan teori semiotika Roland Barthes; dan (5) Menarik kesimpulan dari makna yang di yang ingin disampaikan oleh iklan Samsung India Service "We'll take care of you, wherever you are".

Fokus penelitian dalam penelitian ini adalah makna yang terkandung dalam iklan Samsung India Service "We'll take care of you, wherever you are". Diperlukan analisa terhadap unsur sinematik, kode nonverbal serta elemen-elemen dalam iklan tersebut. Unsur-unsur tersebut, antara lain (1) Elemen, meliputi shot, angle, dan scene; serta (2) Visualisasi dalam film, meliputi wardrobe, backsound, acting, dan peran pemain.

\section{HASIL DAN PEMBAHASAN}

Samsung merupakan salah satu perusahan elektronik terbesar di dunia yang didirikan oleh Lee Byung-Chull pada 1 Maret 1938, yang memulai bisnis nya di Taegu, Korea dengan berdagang mie dan barang-barang lainnya yang diproduksi di Korea dan mengekspornya ke China dan Jepang selama Perang Dunia ke-II (Andi, 2019). Samsung melakukan kampanye mengenai pelayanan mereka lewat sebuah video yang ditayangkan di Youtube. Iklan ini berjudul Samsung India Service "We'll take care of you, wherever you are". Iklan ini menjadi sebuah objek dari penelitian yang akan dilakukan peneliti. Konsep iklan ini dibuat oleh Cheil WW India. Iklan ini telah menjadi iklan yang paling banyak ditonton di kategori Elektronik dan Smartphone di seluruh dunia dan iklan yang paling banyak ditonton di Youtube di semua kategori di India (Samsung Newsroom, 2016). 


\section{Analisis Tanda pada Iklan secara Denotasi}

Pada analisis semiotika Barthes berdasarkan tanda yang ada pada iklan, hasil analisis denotasi dideskripsikan berdasarkan urutan waktu iklan, antara lain (1) Durasi 0:00 - 0:17, menunjukkan seorang petugas Samsung menaiki mobil van sambal menelepon pelanggan yang komplain mengenai TV di rumahnya. Terdapat logo putih biru milik "Samsung" dan pengambilan gambar menggunakan teknik estabilishing shot, medium close up, dan medium shot; (2) Durasi 0:17 - 0:23, petugas Samsung dalam perjalanan ke rumah pelanggan yang diiringi backsound berbahasa India dengan teknik pengambilan gambar estabilishing shot; (3) Durasi 0:24 0:27, Sebuah van Samsung melintasi jembatan gantung dan sungai dengan teknik pengambilan gambar estabilishing shot; (4) Durasi 0:28 - 0:30, teknik pengambilan gambar medium close up menunjukkan petugas Samsung kedinginan; (5) Durasi $0: 30-0: 42$, terdapat pohon tumbang yang menghalangi mobil petugas Samsung. Beberapa teknik pengambilan gambar yang digunakan adalah estabilishing shot, medium close up, dan medium shot; (6) Durasi 0:45 - 0:47, petugas Samsung menendang dan mendorong pohon yang tumbang. Warna dominan pada scene ini berwarna biru dengan gradasi cokelat; (7) Durasi 0:50 - 0:59, mobil van Samsung memutar balik arah melewati pasir, sungai, batuan terjal, hingga melewati bukit berkabut dengan backsound yang berlirik "embrace them with all your heart"; (8) Durasi 1:01 - 1:22, teknik pengambilan gambar yang digunakan establishing shot, menunjukkan sebuah desa yang diambil gambar dari atas. mobil van Samsung yang terhalang oleh sang pengembala domba dan gerombolan domba berwarna putih, putih dan hitam. Adanya gerombolan domba tersebut menghalangi jalan sehingga petugas Samsung menelepon pelanggannya bahwa ada sedikit halangan untuk segera sampai rumahnya. Di dalam scene ini juga terdapat tulisan kecil di sebelah kiri berwarna putih yang beriisi "No animals were harmed while recording this TVC." (9) Durasi 1:23 - 1:26, teknik pengambilan gambar medium shot, menunjukkan petugas Samsung mengayunkan tangannya mencoba untuk menggiring domba agar tidak menghalangi aksesnya untuk melanjutkan perjalanan. Warna dominan pada scene ini berwarna biru tua; (10) Durasi 1:27 - 1:38, petugas Samsung sampai di depan rumah pelanggannya yang berada di belakang gunung dan pepohonan berkabut. Warna dominan pada scene ini adalah biru buram hingga biru tua dengan teknik pengambilan gambar close up, estabilishing shot, dan medium shot; (11) Durasi 1:39 - 1:52, petugas Samsung membawa tasnya sambal memencet bel rumah dan pelanggannya membukakan pintu; (12) Durasi 1:53 - 2:02, pelanggan menyuruhnya masuk untuk mengecek TV. Pelanggan berjalan sambil meraba-raba dinding rumah dan terdapat foto/lukisan yang digantung, seorang lakilaki bernama Louis Brailee. Teknik pengambilan gambar pada scene ini adalah medium close up, medium shot, dan full shot; (13) Durasi 2:05 - 2:23, petugas Samsung sedang memperbaiki TV dan menggulung sebuah kabel putih. Ketika TV selesai dipasang kembali ke dinding, TV sudah selesai diperbaiki dengan backsound suara TV sedang menyala; (14) Durasi 2:26 2:36, pelanggan tersebut berjalan menuju pintu lalu membunyikan lonceng. Di samping lonceng terdapat sebuah papan hitam yang digantung didinding yang berisi "Blind Hostel". Kemudian, terdengar suara kaki-kaki anak kecil menuruni tangga. Warna dominan pada scene ini berwarna cokelat tua; (15) Durasi 2:37 - 2:59, beberapa anak kecil saling berpegangan bahu-membahu. Seorang gadis kecil tersenyum lebar dan 3 anak laki-laki yang berpegangan pada bahu. Remot TV diberikan kepada gadis itu untuk 
menyalakan TV. Terdengar latar suara dari TV yang mengatakan "The first contestant for the night is our favourite, Prerna" berasal dari host TV; (16) Durasi 3:00 3:21, TV menampilkan ajang pencarian bakat dengan pemeran seorang gadis yang menyanyi merdu bernama Prerna. Gadis yang memegang remot berkata pada petugas Samsung, "She is from this hostel, and she is my best friend too" berlatar belakang dua orang perempuan dengan efek blur; (17) Durasi 3:21 - 4:00, Fokus dalam pengambilan gambar ini ialah petugas Samsung dengan ekspresi datar sedikit tersenyum, dengan latar belakang blur. Setelah itu, petugas tesebut menuju pintu keluar mengarah ke mobil van Samsung. Teknik pengambilan gambar yang digunakan establishing shot, terlihat mobil van Samsung melintas di jalan yang gelap, latar belakang dari scene ini ialah bukit dan awan yang terlihat senja atau malam hari. Backsound dari scene ini adalah seorang laki-laki berkata "That's why Samsung Service Vans go to every corner of the country". Durasi 4:00 muncul logo Samsung berwarna putih yang hanya berupa tulisan. Warna dominan pada scene ini berwarna hitam.

\section{Analisis Tanda pada Iklan secara Konotasi}

Konotasi merupakan bentuk lanjut dari sebuah pemaknaan, dalam konotasi, peneliti tidak melihat hanya dengan tataran fisik semata, melainkan maksud dari tanda tersebut.

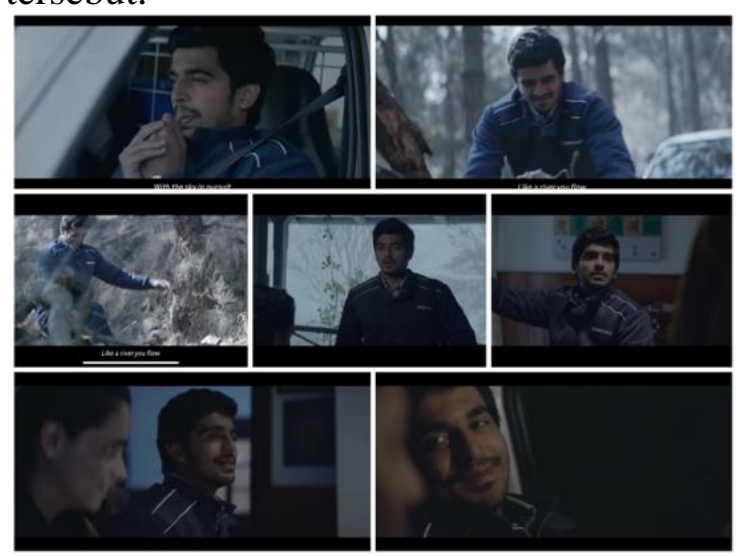

Gambar 1. Cuplikan 1 Iklan Samsung India Service - We'll Take Care of You, Wherever You Are", 2016.

(Sumber: Samsung India, 2016)

Tabel 1. Tanda Naratif dan Sinematik

\begin{tabular}{|c|c|}
\hline Elemen & Deskripsi \\
\hline $\begin{array}{l}\text { Scene, Shot } \\
\text { dan Angle }\end{array}$ & $\begin{array}{l}\text { Medium shot \& Eye level: } \\
\text { durasi } 0: 29 \text {, durasi } 0: 43 \text {, } \\
\text { durasi } 0: 46 \text {, durasi } 1: 48 \text {. } \\
\text { Medium close up \& eye } \\
\text { level: durasi } 2: 35 \text {, durasi } \\
\text { 3:03, durasi 3:51. }\end{array}$ \\
\hline Wardrobe & $\begin{array}{l}\text { jaket berwarna biru } \\
\text { berlogo Samsung. }\end{array}$ \\
\hline Backsound & $\begin{array}{l}\text { Beh Challa Song } \\
\text { Soundtrack. }\end{array}$ \\
\hline $\begin{array}{l}\text { Akting dan } \\
\text { Peran } \\
\text { pemain }\end{array}$ & $\begin{array}{lr}\text { Akting petugas } & \text { Samsung, } \\
\text { menunjukkan } & \text { beberapa } \\
\text { komunikasi } & \text { non-verbal } \\
\text { yang dapat dilihat dari } \\
\text { ekspresi } \\
\text { Samsung. }\end{array}$ \\
\hline
\end{tabular}

Sumber: Data Olahan Peneliti, 2020

Pada gambar 1, memperlihatkan petugas Samsung (Amit) dalam iklan ini, setiap gambar menunjukkan ekspresi wajah yang berbeda-beda dengan teknik pengambilan gambar medium close up, medium shot dan sudut eye level. Pada gambar satu, dua, tiga, dan enam menunjukkan lokasi di luar ruangan, sedangkan pada gambar empat dan lima lokasi di dalam ruangan.

Pada bagaian pertama gambar 1, petugas Samsung (Amit) dapat dimaknai bahwa suhu udara saat itu dingin karena dengan memegang tangan satu sama lain dan meniup udara dari mulut merupakan gambaran jika seseorang membutuhkan kehangatan. Pada gambar 1 bagaian kedua dan ketiga, dapat dimaknai secara nonverbal (Semantik) yang berarti petugas Samsung (Amit) sedang berusaha mendorong dengan tangan dan kaki ke pohon tumbang yang menghalangi jalur yang seharusnya dilintasi oleh mereka. 
Pengambilan gambar menggunakan teknik medium shot yang dapat dimaknai agar penonton mampu melihat petugas Samsung (Amit) yang sedang berusaha mendorong pohon tumbang ditengah jalan. Pada gambar keempat, ekspresi yang ditunjukkan oleh petugas Samsung (Amit) terlihat terkejut dan bingung yang berarti ini merupakan impresi pertama saat petugas Samsung (Amit) melihat gadis tersebut. Pengambilan gambar menggunakan teknik medium close up yang dapat dimaknai agar penonton mampu melihat secara dekat ekspresi yang ditunjukkan oleh petugas Samsung (Amit). Pada gambar kelima, menunjukkan ekspresi petugas Samsung (Amit) terlihat kebingungan. Pengambilan gambar menggunakan teknik medium close up yang dapat dimaknai agar penonton mampu melihat secara dekat ekspresi yang ditunjukkan oleh petugas Samsung (Amit). Pada gambar keenam dan ketujuh, terlihat ekspresi petugas Samsung senang dan bahagia melihat kesekelilingnya. Pengambilan gambar menggunakan teknik medium close up pada gambar keenam yang dapat dimaknai agar penonton mampu melihat secara dekat ekspresi yang ditunjukkan oleh petugas Samsung (Amit). Sedangkan, paada gambar ketujuh pengambilan gambar menggunakan teknik close up yang dapat dimaknai agar penonton mampu melihat secara dekat ekspresi yang ditunjukkan oleh petugas Samsung (Amit).

Warna yang dominan yang muncul di ketujuh gambar ini adalah biru. warna biru dimaknai sebagai langit, surga, harapan, kebahagiaan, ketenangan (Danesi, 2010: 48). Biru juga menggambarkan suasana yang bahagia. Makna warna biru yang muncul dalam scene ini adalah kebahagiaan. Warna biru pun merupakan warna dasar dari logo Samsung dan jaket yang dikenakan oleh petugas Samsung (Amit).

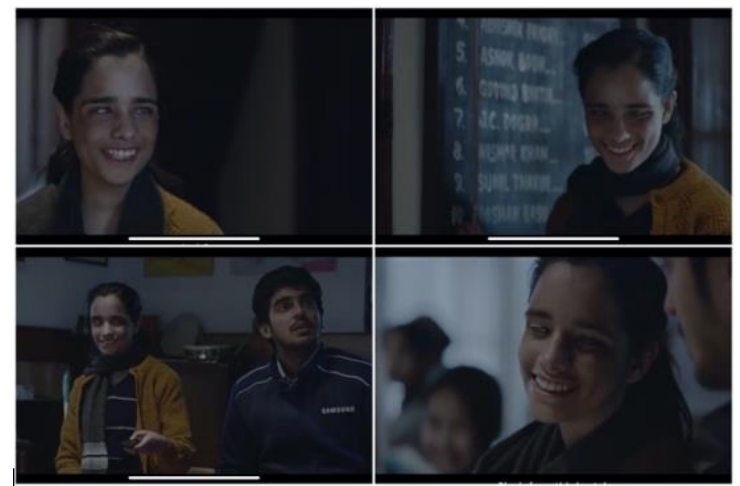

Gambar 2. Cuplikan 2 Iklan Samsung India Service - We'll Take Care of You, Wherever You Are", 2016.

(Sumber: Samsung India, 2016)

Tabel 2. Tanda Naratif dan Sinematik

\begin{tabular}{ll}
\hline \multicolumn{1}{c}{ Elemen } & \multicolumn{1}{c}{ Deskripsi } \\
\hline Scene, Shot & Medium close up \& Eye \\
dan Angle & level: Durasi 1:53, Durasi \\
& 2:33, dan Durasi 3:21 \\
& Medium shot \& Eye level: \\
& Durasi 2:54 \\
\hline Wardrobe & Jaket rajut berwarna \\
& kuning, kaos stripe dan \\
& syal abu-abu dengan garis \\
& putih. \\
\hline Backsound & - \\
\hline Akting dan & akting pelanggan \\
Peran & Samsung, menunjukkan \\
pemain & beberapa komunikasi \\
& non-verbal yang dapat \\
& dilihat dari ekspresi \\
& pelanggan Samsung. \\
\hline
\end{tabular}

Sumber: Data Olahan Peneliti, 2020

Pada gambar 2, memperlihatkan pelanggan Samsung dalam iklan ini, setiap gambar menunjukkan ekspresi wajah yang sama dengan teknik pengambilan gambar ketiga menggunakan medium close up dan pengambilan gambar pertama, kedua, keempat menggunakan close up dengan sudut eye level. Semua gambar menunjukkan lokasi di dalam ruangan. Pengambilan gambar menggunakan teknik medium close up agar penonton mampu melihat jelas kekurangan yang dimiliki pelanggan Samsung, yaitu tuna netra. 
Pada gambar 2 bagian pertama, menunjukkan pelanggan Samsung yang telah membukakan pintu dengan ekspresi tersenyum lebar. Pada gambar kedua, menunjukkan pelanggan Samsung yang sedang memegang tali yang dapat membunyikan sebuah lonceng diatasnya sambil berkata "Come fast...hurry...the show is about to begin" Hal ini dapat dimaknai dengan kode non-verbal yang termasuk kedalam dimensi Sintatik yaitu, Hal ini mengacu kepada cara tanda yang disusun atau terorganisir (Morissan, 2013: 142) bahwa pelanggan Samsung telah membunyikan sebuah bel untuk memanggil anak-anak tuna netra lainnya untuk turun ruang $\mathrm{TV}$, dengan berlatar belakang sebuah papan hitam dengan tulisan berwarna putih terpasang di dinding. Pada gambar ketiga, menunjukkan petugas Samsung (Amit) menunjukkan ekspresi bingung, sedangkan ekspresi pelanggan Samsung menunjukkan ekspresi senang karena ia sedang tersenyum. Pada gambar keempat, menunjukkan pelanggan Samsung sedang menghadap ke petugas Samsung (Amit) tersenyum sambil berkata "She is from this hostel and she is my best friend too". Hal ini dapat dimaknai secara non-verbal (Semantik) ekspresi pelanggan Samsung menunjukkan ekspresi senang dan bangga. Pengambilan gambar menggunakan teknik close up .

Warna yang dominan yang muncul di keempat gambar ini adalah kuning. Warna kuning dimaknai sebagai cahaya matahari, ketenangan, perdamaian. Makna warna kuning yang muncul dalam keempat gambar ini adalah perdamaian. Hal ini dapat dilihat bahwa pelanggan Samsung menggambarkan sifat yang damai ataupun rukun.

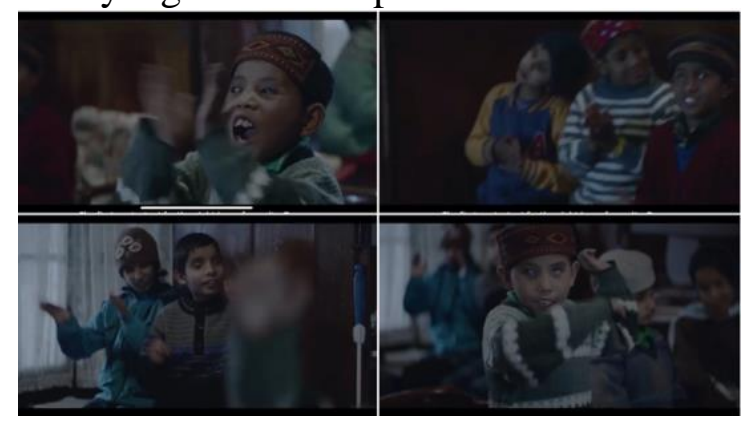

Gambar 3. Cuplikan 3 Iklan Samsung India Service - We'll Take Care of You, Wherever You Are", 2016.

(Sumber: Samsung India, 2016)

Tabel 3. Tanda Naratif dan Sinematik

\begin{tabular}{|c|c|}
\hline Elemen & Deskripsi \\
\hline $\begin{array}{l}\text { Scene, Shot } \\
\text { dan Angle }\end{array}$ & $\begin{array}{l}\text { Medium close up \& Eye } \\
\text { level: Durasi 3:02, Durasi } \\
\text { 3:10, Durasi 3:27, dan } \\
\text { Durasi 3:28 }\end{array}$ \\
\hline Wardrobe & $\begin{array}{l}\text { Jaket rajut stripe putih } \\
\text { hijau dengan topi } \\
\text { berwarna merah dan } \\
\text { hitam, jaket baseball } \\
\text { berwarna biru dan kuning } \\
\text { dengan topi beanie, jaket } \\
\text { rajut dengan dalaman } \\
\text { kaos biru berkerah dan } \\
\text { topi berwarna hitam garis } \\
\text { coklat dan jaket berwarna } \\
\text { hijau tosca dengan topi } \\
\text { beanie coklat. }\end{array}$ \\
\hline Backsound & $\begin{array}{l}\text { Beh Challa Song } \\
\text { Soundtrack. }\end{array}$ \\
\hline $\begin{array}{l}\text { Akting dan } \\
\text { Peran } \\
\text { pemain }\end{array}$ & $\begin{array}{lr}\text { Akting } & \text { pemeran } \\
\text { pendukung } & \text { yang } \\
\text { merupakan beberapa anak } & \text { laki-laki rang } \\
\text { menunjukkan } & \text { komunikasi } \\
\text { non-verbal } & \text { melalui } \\
\text { ekspresi dan gerakan. }\end{array}$ \\
\hline
\end{tabular}

Sumber: Data Olahan Peneliti, 2020

Pada gambar 3 menunjukkan beberapa pemeran pendukung yang terdiri dari anakanak tuna netra yang sedang duduk, berdiri sambil bertepuk tangan dan menari saat mendengarkan salah satu dari temannya (Prerna) yang sedang bernyanyi di ajang pencarian bakat. Teknik pengambilan gambar medium close up.

Pada gambar pertama dan kedua, menunjukkan para pemeran pendukung turut bangga menyaksikan Prerna saat bernyanyi diajang pencarian bakat. Teknik pengambilan gambar yang digunakkan medium close up yang dimaknai agar 
penonton mampu melihat beberapa pemeran pendukung. Pada gambar ketiga dan keempat, menunjukkan para pemeran pendukung yang sedang menari, menggerakkan kedua tangan dan tubuh ke kanan dan kiri menikmati lagu yang dinyanyikan. Beberapa pemeran pendukung mengenakan sweater atau lengan panjang dan topi. Makna dari pakaian yang digunakan para pemeran pendukung menunjukkan bahwa suhu ruangan di lokasi cukup dingin karena berlokasi di Manalli, Himachal Pradesh, India Utara. Cuaca pada musim dingin di Manalli, mampu mencapai $-10^{\circ} \mathrm{C}$.

\section{Analisis iklan secara Mitos}

Mitos merupakaan bentuk lanjut dari sebuah pemaknaan semiotika. Dalam mitos, peneliti tidak melihat hanya dengan tataran fisik semata, namun sudah mengarah ke sebuah sejarah yang berhubungan kepada tanda tersebut.

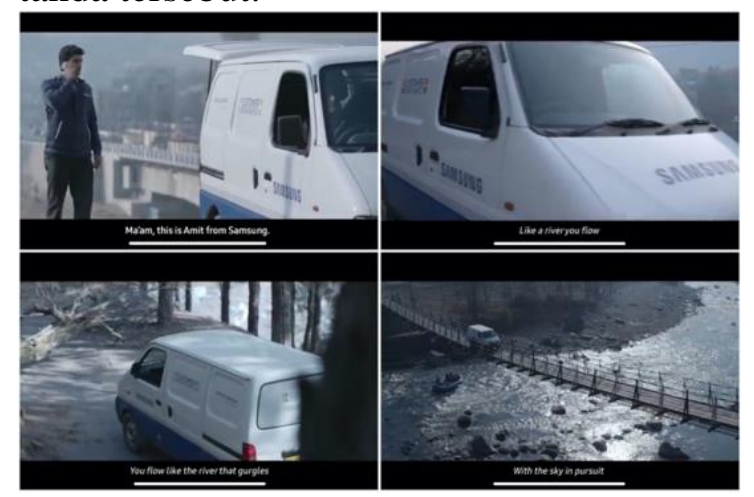

Gambar 4. Cuplikan 4 Iklan Samsung India Service - We'll Take Care of You, Wherever You Are”, 2016. (Sumber: Samsung India, 2016)

Tabel 4. Tanda Naratif dan Sinematik

\begin{tabular}{ll}
\hline \multicolumn{1}{c}{ Elemen } & \multicolumn{1}{c}{ Deskripsi } \\
\hline Scene, Shot & Medium shot \& Eye level: \\
dan Angle & Durasi 0:07 dan Durasi \\
& $0: 21$ \\
& Medium shot \& High \\
& angle: Durasi 0:27 \\
& Establishing shot \& Bird \\
& view: Durasi 0:38
\end{tabular}

\begin{tabular}{llr}
\hline Wardrobe & $\begin{array}{l}\text { Jaket biru } \\
\text { Samsung. }\end{array}$ \\
\hline Backsound & $\begin{array}{l}\text { Beh Challa } \\
\text { Soundtrack. }\end{array}$ \\
\hline Akting dan & Akting petugas Samsung, \\
Peran & menunjukkan beberapa \\
pemain & komunikasi non-verbal \\
& $\begin{array}{l}\text { yang dapat dilihat dari } \\
\text { ekspresi pemeran utama }\end{array}$ \\
& dalam durasi 0:07. \\
\hline
\end{tabular}

Sumber: Data Olahan Peneliti, 2020

Pada gambar 4, memperlihatkan pengambilan gambar mobil van Samsung dengan sudut pengambilan gambar yang berbeda beda. Keempat dari gambar samasama diambil dari luar ruangan dengan objek yang sama yaitu mobil van Samsung berwana mayoritas warna putih dan biru di bagian bawah mobil dengan latar tempat yang berbeda-beda. Backsound dari iklan ini pun merupakan suara seorang laki-laki yang bernyanyi dengan bahasa India.

Warna yang dominan yang muncul di keempat gambar ini adalah biru. Biru menggambarkan suasana yang dingin atau sejuk. Makna warna biru yang muncul dalam scene iklan adalah harapan. Warna biru pun merupakan warna dasar dari logo Samsung.

Sudut pengambilan gambar dalam sebuah objek juga tentunya menimbulkan makna tertentu. Medium shot merupakan pengambilan gambar yang meliputi kepala hingga area paha (Tobing, 2018: 8), makna dari pengambilan gambar pertama adalah untuk memperlihatkan bahwa pemeran utama (Amit) adalah seorang teknisi dari Samsung India. Hal ini dapat didukung oleh jaket biru yang dikenakan oleh Amit. Jaket biru inipun mampu dikatakan seragam teknisi Samsung India karena memiliki logo Samsung dan bertulisan Customer Service di bagian punggung jaket. Eye level merupakan pengambilan gambar yang sejajar dengan posisi objek utama (Bonafix, 2011), makna pengambilan gambar dari sudut eye level adalah untuk memudahkan penonton untuk melihat mobil van Samsung secara 
keseluruhan. Sedangkan, Bird view dan high level dapat dimaknai agar penonton mampu untuk melihat secara keseluruhan lintasan yang dilewati oleh mobil van Samsung,

Berdasarkan hasil penelitian yang telah dikonfrimasi dari beberapa website Samsung mengenai mobil van Samsung, Samsung India adalah negara terbesar dan perusahaan elektronik yang paling dipercaya oleh konsumen, telah mengumumkan inisiatif pelayanan pelanggan yang unik untuk seluruh konsumen di India yaitu membawa layanan kelas dunia ke depan pintu pelanggan di perkotaan maupun perdesaan. Lebih dari 250 titik servis dan lebih dari 250 teknisi yang telah ditambahkan dalam satu bulan, teknisi akan dilokasikan didaerah terpencil dan membantu untuk menjangkau setiap konsumen Samsung di daerah mereka. Mobil van Samsung akan membantu Samsung untuk memberikan layanan kelas dunia "Anytime, Everywhere". Konsumen Samsung dapat mengakses layanan mobil van Samsung dengan menghubungi nomor 1800-40-SAMSUNG (1800-40-7267864) (Samsung Newsroom, 2016).

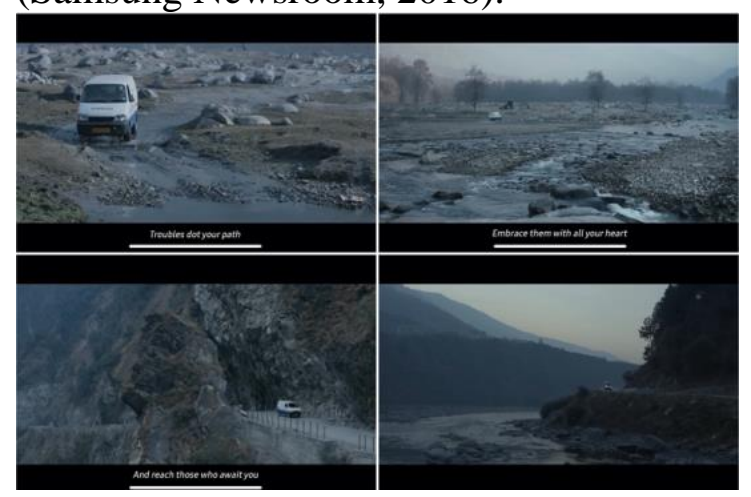

Gambar 5. Cuplikan 5 Iklan Samsung India Service - We'll Take Care of You, Wherever You Are", 2016.

(Sumber: Samsung India, 2016)

Tabel 5. Tanda Naratif dan Sinematik

\begin{tabular}{ll}
\hline \multicolumn{1}{c}{ Elemen } & \multicolumn{1}{c}{ Deskripsi } \\
\hline Scene, Shot & Establishing shot \& Bird \\
dan Angle & View: Durasi 0:53, Durasi \\
& $0: 56$, Durasi 1:03 dan \\
& Durasi 1:28 \\
\hline
\end{tabular}

\begin{tabular}{lll}
\hline Wardrobe & - & \\
\hline Backsound & $\begin{array}{l}\text { Beh Challa Song } \\
\text { Soundtrack. }\end{array}$ & \\
& Akting dan & - \\
Peran & \\
pemain & & \\
\hline
\end{tabular}

Sumber: Data Olahan Peneliti, 2020

Pada gambar 5, memperlihatkan mobil van Samsung yang sama, namun jenis jalur lintasan yang berbeda beda, dengan teknik pengambilan yang sama yaitu establishing shot dan sudut bird view. Warna yang dominan yang muncul di keempat gambar ini adalah abu-abu. warna abu-abu dimaknai sebagai berkabut, kabur, misteri (Danesi, 2010: 48). Makna warna abu-abu yang muncul dalam scene iklan adalah berkabut. Warna abu-abu terlihat sangat dominan dikarenakan suasana pegunungan, sungai, dan pepohonan yang diselimuti kabut.

Pengambilan gambar dalam objek ini adalah establishing shot merupakan pengambilan gambar suatu lokasi untuk memberikan sebuah gambaran keadaan di lokasi yang berhubungan langsung dengan objek (Tobing, 2018: 12), yaitu mobil van Samsung yang sedang melintas. Sedangkan, Bird view dapat dimaknai agar penonton mampu untuk melihat secara keseluruhan lintasan yang dilewati oleh mobil van Samsung. Makna lain yang dapat disimpulkan, bahwa perjalanan dengan lintasan yang menyeramkan tidak membuat pengemudi dan teknisi Samsung untuk menyerah.

Peneliti pun meneliti lokasi atau jalur lintasan yang dijangkau oleh mobil van Samsung. Dari beberapa website yang telah diteliti, peneliti menemukan lokasi yang terlihat sama dengan lokasi pembuatan iklan ini, yaitu di Manali. Manali adalah bagian dari salah satu kawasan yang terletak di India Utara, Himachal Pradesh. Manali merupakan kota dataran tinggi di India, lokasinya berada tepat di kaki pegunungan Himalaya, di perbatasan antara empat negara yaitu, India, Nepal, China, dan Tibet. 
Negara-negara tersebut hanyalah dipisahkan oleh pegunungan dikawasan Himalaya. Perjalanan yang harus ditempuh menggunakan bus dari pusat kota New Delhi menuju kota Manali yaitu selama kurang lebih 12 jam perjalanan. Secara umum, India bagian Utara memiliki tiga periode siklus musim dalam satu tahun, musim dingin berlangsung mulai dari akhir Oktober sampai dengan penghujung Maret. Cuaca pada musim dingin mampu mencapai $-10^{\circ} \mathrm{C}$. Sedangkan, musim semi yang berlangsung lebih singkat, pada umumnya hanya berlangsung selama tiga minggu diantara Maret dan April (Taufan, 2019). Sedangkan, sungai yang membentang dihampir sepanjang lintasan yang dilewati mobil van Samsung ini adalah sungai Beas. Sungai Beas berada diketinggian 14.308 kaki (4.361 meter) di Pass Rohtang, Himalaya Barat, bagian dari jajaran pegunungan Himalaya. Sungai Beas mengalir ke arah Selatan melalui Lembah Kullu yang diapit pegunungan setelah itu mengarah kearah Barat melalui Mandi ke Lembah Kangra (Britannica.com, n.d.-a). Sungai ini pun terbagi menjadi tiga arah yang akan tergabung kembali setelah melintasi Mirthal yang berada diketinggian 980 kaki diatas permukaan laut, anak-anak sungai Beas adalah sungai Bain, sungai Banganga, sungai Luni dan Uhal, bersamaan dengan sungai Banner, sungai Chakki, sungai Gaj, sungai Mamuni, sungai Parvati, sungai Patlikuhlal, sungai Sainj, sungai Suketi dan sungai Tirthan. Total Panjang Sungai Beas adalah $470 \mathrm{~km}$. Sungai ini berfungsi sebagai sumber air bagi seluruh kota dan desa yang termasuk dalam jalur sungai (mapsofindia.com, 2014).

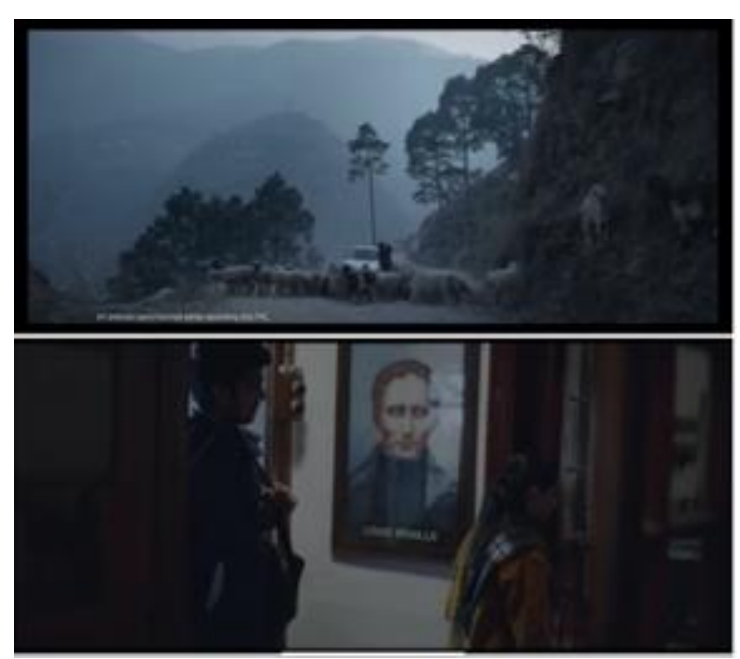

Gambar 6. Cuplikan 6 Iklan Samsung India Service - We'll Take Care of You, Wherever You Are", 2016. (Sumber: Samsung India, 2016)

Tabel 6. Tanda Naratif dan Sinematik

\begin{tabular}{|c|c|}
\hline Elemen & Deskripsi \\
\hline $\begin{array}{l}\text { Scene, Shot } \\
\text { dan Angle }\end{array}$ & $\begin{array}{l}\text { Establishing shot \& Eyel } \\
\text { level: Durasi } 1: 12 \\
\text { Medium shot \& Eye level: } \\
\text { Durasi } 1: 56 \text {, dan Durasi } \\
\text { 2:01 }\end{array}$ \\
\hline Wardrobe & $\begin{array}{l}\text { Durasi } 1: 12, \quad \text { jaket } \\
\text { berwarna biru berlogo } \\
\text { Samsung, durasi 1:56 dan } \\
\text { durasi 2:01 jaket biru } \\
\text { berlogo Samsung dan } \\
\text { jaket rajut berwarna } \\
\text { kuning, kaos stripe dan } \\
\text { syal abu-abu dengan garis } \\
\text { putih }\end{array}$ \\
\hline Backsound & $\begin{array}{l}\text { Durasi } 1: 12 \text {, Beh Challa } \\
\text { Song Soundtrack. }\end{array}$ \\
\hline $\begin{array}{l}\text { Akting dan } \\
\text { Peran } \\
\text { pemain }\end{array}$ & $\begin{array}{l}\text { Akting pelanggan dan } \\
\text { petugas } \\
\text { menunjukkan } \quad \text { Samsung } \\
\text { komunikasi non-verbal. }\end{array}$ \\
\hline
\end{tabular}

Pada gambar 6, memperlihatkan lintasan yang telah terhalangi oleh gerombolan domba dengan latar belakang pepohonan dan gunung. Namun, di setiap scene yang terlihat ada segerombolan domba, Samsung menuliskan sebuah note di sebelah kiri dari frame yang berkata "No 
animals were harmed while recording this TVC'. Hal ini dapat dimaknai bahwa Samsung India ingin memberikan informasi kepada penonton bahwa selama proses pembuatan iklan ini, tidak ada hewan yang terlukai. Menurut pandangan peneliti, informasi ini penting untuk diberitahu kepada penonton agar tidak ada kesalahpahaman antara Samsung India dengan penonton atas adanya hewan dalam proses pembuatan iklan ini. Teknik pengambilan gambar yang digunakkan medium shot yang dimaknai agar penonton mampu melihat secara detail setiap objek dan note yang ditampilkan disebelah kiri frame tidak akan mengganggu objek yang ada di scene ini.

Pada gambar 6, memperlihatkan proses pemeran utama (Amit) yang telah masuk kedalam rumah seorang pemeran kedua (seorang gadis) dengan latar belakang sebuah dinding yang digantungi foto besar seseorang tokoh yang bertuliskan nama Louis Braille. Peneliti pun mencari sebuah informasi mengenai foto yang terpajang di dinding tersebut. Seorang pria tokoh pria tersebut adalah Louis Braille yang terlahir pada tanggal 4 Januari 1809 di Coupvray, Paris, Perancis dan meninggal dunia pada 6 januari 1852 di Paris dikarenakan penyakit TBC (Britannica.com, n.d.-b). Saat beliau berusia 15 tahun, beliau menciptakan sebuah enam titik timbul dengan tiga titik berbaris kebawah dan dibagi menjadi dua kolom, lalu titik-titik timbul tersebut pun dikembangkan menjadi tanda baca, sehingga akhirnya tercipta sekital 64 simbol yang dapat digunakan oleh para tuna netra. Dalam buku pertama yang beliau luncurkan pada usia 15 tahun, beliau menambahkan simbol untuk matematika dan musik. Berkat hasil penemuan beliau, para tuna netra di seluruh dunia mampu membaca, menghitung dan belajar musik. Jasa beliau begitu besar, huruf ini kemudian diberi nama huruf Braille yang diambil dari nama belakang seorang Louis Braille (Britannica.com, n.d.-b). Untuk mengenang jasanya, sejak tahun 1956 bekas rumahnya yang terletak di Coupvray, $20 \mathrm{~km}$ sebelah Timur dari Paris, telah dijadikan sebagai museum Louis Braille.

\section{Makna Iklan Samsung India Service "We'll Take Care of You Wherever You Are"}

Berdasarkan makna yang terdapat di dalam ikan Samsung India Service "We'll take care of you wherever you are", pesan yang nampak pada iklan secara keseluruhan adalah dengan munculnya adegan-adegan yang diperani, rintangan, dan lintasan jalur yang harus dilewati oleh Amit untuk sampai ke lokasi pelanggan Samsung yang berada di sebuah desa yang jauh dari pusat kota. Dari adegan yang terlihat di dalam Iklan ini menunjukkan bahwa layanan yang ditawarkan Samsung India tidaklah biasa karena Samsung India mampu mengantarkan pelayanan langsung ke lokasi pelanggan meskipun harus menempuh jarak yang jauh ataupun rintangan yang sulit. Samsung India tetap berkomitmen untuk tetap melayani pelanggan dengan sepenuh hati. Iklan ini pun menunjukkan kepuasan pelayanan yang diberikan oleh pihak Samsung India. Pemeran utama yang berperan menjadi petugas Samsung India yang terlihat bangga atas pelayanan yang telah ia berikan kepada pelanggan Samsung India.

\section{Temuan}

Iklan Samsung India Service "We'll take care of you, wherever you are" memiliki kumpulan tanda yang dapat dimaknai oleh para target audiens. Iklan ini pun dibuat untuk mempromosikan pelayanan yang dilakukan oleh Samsung India melalui tanda-tanda yang ada di dalam iklan tersebut. Penggunaan dan penyusunan tanda-tanda yang kurang terorganisir secara linier dapat menyebabkan timbulnya perbedaan pemahaman pada kalangan masyakat yang menonton iklan ini. Hal ini menjadi penting untuk diteliti oleh peneliti. 
Adanya unsur rintangan yang harus dilalui oleh pemeran utama (Amit) untuk sampai ke lokasi konsumen Samsung yang berada di sebuah desa yang jauh dari pusat kota. Rintangan yang harus dilewati oleh Amit cukup sulit, hal ini ditunjukkan dari beberapa hal yang menghalangi lintasan mobil van Samsung tersebut. Dalam hal ini menurut peneliti, pemilihan media untuk mempublikasikan iklan ini tepat, karena Youtube merupakan sosial media yang mampu diakses oleh masyarakat secara luas, secara nasional maupun internasional. Sehingga, target audiens menjadi sangat luas dengan usia yang beragam.

Temuan baru lainnya yang terkait dengan tingginya antusias penonton secara positif dapat dilihat dengan banyaknya youtuber yang membuat reaksi video terhadap iklan ini, komentar positif, penonton yang melampaui 210 juta penonton di youtube dengan 189,323 likes, dan media online pun memberitakan iklan ini secara positif. Hal ini dapat disimpulkan bahwa kebanyakan dari penonton iklan ini memberikan feedback yang positif.

Temuan baru lainnya dapat dilihat bahwa pihak perusahaan yaitu Samsung India merupakan perusahaan yang kredibel karena pihak perusahaan terus menonjolkan logo Samsung di dalam iklan tersebut. Hal ini menunjukkan bahwa Samsung India ingin membentuk pola pikir penonton agar merek Samsung India berada di Top of Mind para penonton.

\section{SIMPULAN}

Dari keseluruhan analisis teori Semiotika yang dilakukan oleh peneliti menggunakan sudut pandang Roland Barthes dengan memahami makna secara denotasi, konotasi dan mitos. Secara denotasi iklan ini merupakan iklan online yang dipublikasikan di Youtube dengan menginformasikan mengenai pelayanan mereka. Iklan ini juga merupakan salah satu cara untuk Samsung India mempromosikan pelayanan yang mereka ingin informasikan kepada pelanggan mereka dan penonton lainnya.

Secara konotasi iklan ini merupakan iklan yang berisikan makna yang dapat dilihat dari jalan cerita iklan ini, akting pemeran iklan dan juga lokasi yang ada didalam iklan ini. Melalui iklan ini Samsung India berharap agar pesan yang ingin mereka sampaikan kepada pelanggan dan penonton lainnya sampai ke benak-nya.

Secara mitos iklan ini merupakan budaya perusahaan untuk melakukan promosi melalu media online yang mereka pilih yaitu Youtube, yang merupakan media sosial yang berisikan video-video dengan banyak kategori, Youtube memiliki segmentasi yang luas karna mampu diakses melalui internet, kapan saja, dan dimana saja. Maka dari itu iklan ini memiliki jumlah penonton yang sangat tinggi.

\section{DAFTAR PUSTAKA}

Andi, D. (2019). Ini Sejarah Samsung dalam Menguasai Industri Elektronik Dunia [News-Teknologi]. Mobi Tekno. https://mobitekno.com/read/2019/17/09 /ini-sejarah-samsung-dalammenguasai-industri-elektronikdunia/\#: :text=Samsung\%20mulai\%20 masuk\%20ke\%20industri,petrokimia\% 2C\%20dan\%20mesin\%20pesawat $\% 20 \mathrm{t}$ erbang.

Anggakara, T. P., \& Gunawan, S. (2017). The Concept of The Luxury Branding In Samsung Galaxy S6 Edge Series Through Triadic Modes of Sign. Kata Kita, 5(1), 142-148. https://doi.org/10.9744/katakita.5.1.142 $-148$

Arasid, M. N., \& Hapsari, R. (2019). Pemaknaan Ilustrasi Berita Infografis Pada Media Online: Analisis semiotika pada Instagram CNBC Indonesia. $J$ IKA, 6(2), 91-98. https://doi.org/10.31294/kom.v6i2.640 3 
Bonafix, D. N. (2011). Videografi: Kamera dan Teknik Pengambilan Gambar. Humaniora, 2(1), 845-854. https://doi.org/10.21512/humaniora.v2i 1.4015

Britannica.com. (n.d.-a). Beas River (River, India) [Article]. Britannica. Retrieved 18 March 2021, from https://www.britannica.com/place/Beas -River

Britannica.com. (n.d.-b). Louis Braille (French Educator) [Article]. Britannica. Retrieved 18 March 2021, from https://www.britannica.com/biography/ Louis-Braille

Christian, M. (2019). Telaah keniscayaan iklan di kanal youtube sebagai perilaku khalayak di kalangan milenial. Bricolage: Jurnal Magister Ilmu Komunikasi, 5(02), 141-211. https://doi.org/10.30813/bricolage.v5i0 2.1890

Danesi, M. (2010). Semiotika Media. Jalasutra.

Fernando, S. (2019). Insecurity and SelfAcceptance Portrayed in Samsung Galaxy A8 Advertisement "Lets You Be You": A Multimodal Analysis. Kata Kita, $\quad 7(2), \quad$ 260-268. https://doi.org/10.9744/katakita.7.2.260 $-268$

Gesenhues, A. (2017). The most-watched ad on YouTube in 2017 was a spot from Samsung India Services [News]. Marketing Land. https://marketingland.com/watched-adyoutube-2017-spot-samsung-indiaservices-229727

Gunawan, A. (2018). 7 Fakta Menarik Samsung yang Tidak Diketahui Oleh Banyak Orang [News]. IDN Times. https://www.idntimes.com/tech/trend/ar if-gunawan/7-fakta-menarik-samsungyang-tidak-diketahui-oleh-banyakorang-c1c2

Kusumasari, R. N. (2014). Makna Iklan Oreo Versi "Pilih Handphone Atau
Oreo" (Studi Fenomenologi Iklan Oreo Versi "Pilih Handphone atau Oreo" Menurut Mahasiswa BSI Bandung). $J$ IKA, $\quad$ l(2), 100-105. https://doi.org/10.31294/kom.v1i2.219 Mapsofindia.com. (2014). Beas RiverCourse Map and its History [Maps]. Maps of India. https://www.mapsofindia.com/maps/riv ers/beas.html

Morissan. (2013). Teori Komunikasi: Individu Hingga Massa. Kencana Prenada Media Group.

Najam, H. (2019). Pes.an Moral dalam Iklan Bukalapak edisi "Bu Linda'di Youtube (Analisis Semiotika Charles Sanders Peirce) [Skripsi]. Universitas Islam Negeri Sunan Ampel Surabaya.

Oputa, E. A., \& Ahmad, F. B. (2019). Semiotic Advertising by International Firms: A Comparative Study of Premium Smart Phone Brands in China, South Korea and USA. International Journal of Applied Business and International Management, 4(1), 3845.

https://doi.org/10.32535/ijabim.v4i1.38 1

Prasetya, A. B. (2019). Analisis Semiotika Film dan Komunikasi. Intrans Publishing.

Rahayu, E., \& Dewi, P. A. R. (2018). Respon Khalayak Terhadap Iklan Komparatif "Samsung Galaxy: Growing Up. Commercium, 2(2), 9-12.

Rahayu, M. N., \& Poerana, A. F. O. L. (2020). Pemanfaatan Instagram dalam Menjaga Hubungan Baik PT. Pupuk Kujang dengan Stakeholders. WACANA: Jurnal Ilmiah Ilmu Komunikasi, 19(2), 186-201.

Rosidin, A. B., \& Hamid, A. (2020). Media Online Dan Kerja Digital Public Relations Politik Pemerintah Dki Jakarta. WACANA: Jurnal Ilmiah Ilmu Komunikasi, 19(2), 164-174. https://doi.org/10.32509/.v19i2.1046 
Samsung Newsroom. (2016). Samsung Goes Bharat, 535 Service Vans to Connect 6,000 Talukas [News-Teknologi]. Samsung Newsroom India. https://news.samsung.com/in/samsunggoes-bharat-535-service-vans-toconnect-6000-talukas

Sobur, A. (2009). Semiotika Komunikasi (1st ed.). Remaja Rosdakarya.

Sukamto, S. M. A., \& Wijaksana, T. I. (2017). Iklan Melalui Youtube dan Minat Beli Produk. Journal of Research and Applications: Accounting and Management, 2(2), 135. https://doi.org/10.18382/jraam.v2i2.16 8

Taufan, F. (2019). Mengunjungi Manali, Kawasan Wisata Salju di Kaki Pegunungan Himalaya [News]. Kumparan.

https://kumparan.com/sulbarkini/meng unjungi-manali-kawasan-wisata-saljudi-kaki-pegunungan-himalaya1550349301390033263

Tito, A. C. P., \& Gabriella, C. (2019). Faktor-faktor Iklan yang Dapat Menarik Penonton Untuk Menonton Iklan Skip-
Ads di Youtube Sampai Selesai. Jurnal Akuntansi Maranatha, 11(1), 98-114. https://doi.org/10.28932/jam.v11i1.154 4

Tobing, D. S. H. (2018). Teknik Pengambilan Gambar. Issu Inc. https://issuu.com/fikri.0797/docs/buku _-_teknik_pengambilan_gambar

Wahjuwibowo, I. S. (2018). Semiotika Komunikasi (3rd ed.). Mitra Wacana Media.

Youtube. (2016). Samsung India Service (SVC)-Most Watched Video in 2017We'll take care of you, wherever you are [Mp4]. Samsung. https://www.youtube.com/watch?v=77 9KwjAYTeQ\&ab_channel=SamsungIn dia

Yuliyanti, F. D., Bajari, A., \& Mulyana, S. (2017). Representasi Maskulinitas Dalam Iklan Televisi Pond's Men \#Lelakimasakini (Analisis Semiotika Roland Barthes Terhadap Representasi Maskulinitas). Jurnal Komunikasi, 9(1), 16-30. https://doi.org/10.24912/jk.v9i1.180 